\title{
On the presence and localization of Brachytrupes megacephalus (Lefebvre, 1827) (Orthoptera Gryllidae) in the "Oriented Natural Reserve Simeto Oasis" (Sicily, Italy)
}

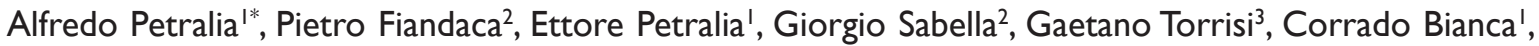 \\ Francesco Lamanna ${ }^{4} \&$ Caterina Dima ${ }^{4}$ \\ ${ }^{1}$ Association "Ente Fauna Siciliana”, Noto, Italy \\ ${ }^{2}$ Department of Biological Geological and Environmental Sciences, University of Catania, Italy \\ ${ }^{3}$ Administration of the Metropolitan City of Catania, Italy \\ ${ }^{4}$ Association "Chloe", Strongoli, Italy \\ ${ }^{*}$ Corresponding author, e-mail: alfredo.petralia@yahoo.it
}

\begin{abstract}
The authors present the results of an investigation aimed to ascertaining the presence of the Gryllidae Brachytrupes megacephalus Lefebvre, 1827, Orthopter of UE interest, in the "Oriented Natural Reserve of Simeto Oasis", located near Catania along the eastern coast of Sicily (Italy). The species is noticeably widespread in the reserve despite of the alterations and disturbance of anthropogenic origin that have affected the entire coastal dune belt of the Catania Gulf. Management measures aimed to the protection the species are also suggested, as well as protocols for its monitoring in the medium-long term in order to keep under control the consolidation and further diffusion of the species in the territory of the reserve.
\end{abstract}

KEY WORDS Biodiversity; ecology; Orthoptera; Brachytrupes; Sicily.

Received 10.06.2021; accepted 01.09.2021; published online 30.12.2021

\section{INTRODUCTION}

Brachytrupes megacephalus is a psammophilous cricket described by Alexandre Lefebvre (1827) on specimens found in Sicily and originally named as Gryllus megacephalus Lefebvre, 1827. Subsequently, it was attributed to the genus Brachytrupes ("short ovipositor") established by AudinetServille (1839) distinguishing it from the genus Gryllus. It is a palearctic species whose distribution area extends in latitude from Niger to Sicily (Chopard, 1943) and south of Sardinia (Zanardi, 1964): in North Africa the species is widespread in the Saharan oasis or in wet "oued"; in the Mediterranean area it is found mainly in the coastal retrodune bands (ISPRA 2016a) including those of the Sicily and Aeolian, Maltese and Pelagie islands.

The cricket is vegetarian, hygrophilous, yellowish, normally crepuscular and nocturnal. It is a bur- rowing animal living in tunnels (different in shape and depth during the biological cycle as highlighted by Conti et al., 2012) that the specimens realize by the expulsion of the sand excavated by means of a very spectacular behavioural pattern involving its forelegs, the robust jaws and the large head (Caltabiano et al., 1979). Such activity produces on the surface the formation of typical little irregular sandy "mounds" (at the mouth of the holes that they dig into the ground) which reveal the presence of the animals (Lefebvre 1827; Chopard, 1943).

It has sexual dimorphism: on the forewings the males have the stridulatory organ with which they produce a song (Brizio, 2018) to attract females in order to mate during breeding season (March-April). After the spawning the animals die. In June the new generation is born, and develops during summer; in late autumn-winter the new-adults remain in the holes up to a depth of 1 
meter in the sandy soil; in the following spring they reproduce and so on. Due to its progressive rarefaction in Europe, in particular during the last century, the species was included in Annexes II and IV of the European Directive 92/43 as species that requires special protection and so considered "Vulnerable" by the IUCN.

The authors present the results of a survey on the status of Brachytrupes megacephalus (Fig. 1) inside the "Oriented Natural Reserve of Simeto Oasis" that extends along the Sicilian Ionian sandy coast just south of the city of Catania (Fig. 2 ): the purpose of this research is to confirm and localize the presence of the species within the boundaries of the reserve in order to provide the Management Authority (the Administration of the Metropolitan City of Catania) with useful information and suggestions for planning appropriate protection measures aimed at limiting the anthropic pressure as well as measures to protect and restore the potential habitats of $B$. megacephalus as fundamental condition for its survival according to the official guidelines envisaged for the protection of habitats and species of UE interest (ISPRA, 2016a, 2016b).

The present study is therefore suggested as a starting point for systematic monitoring actions of the species according to its conservation.

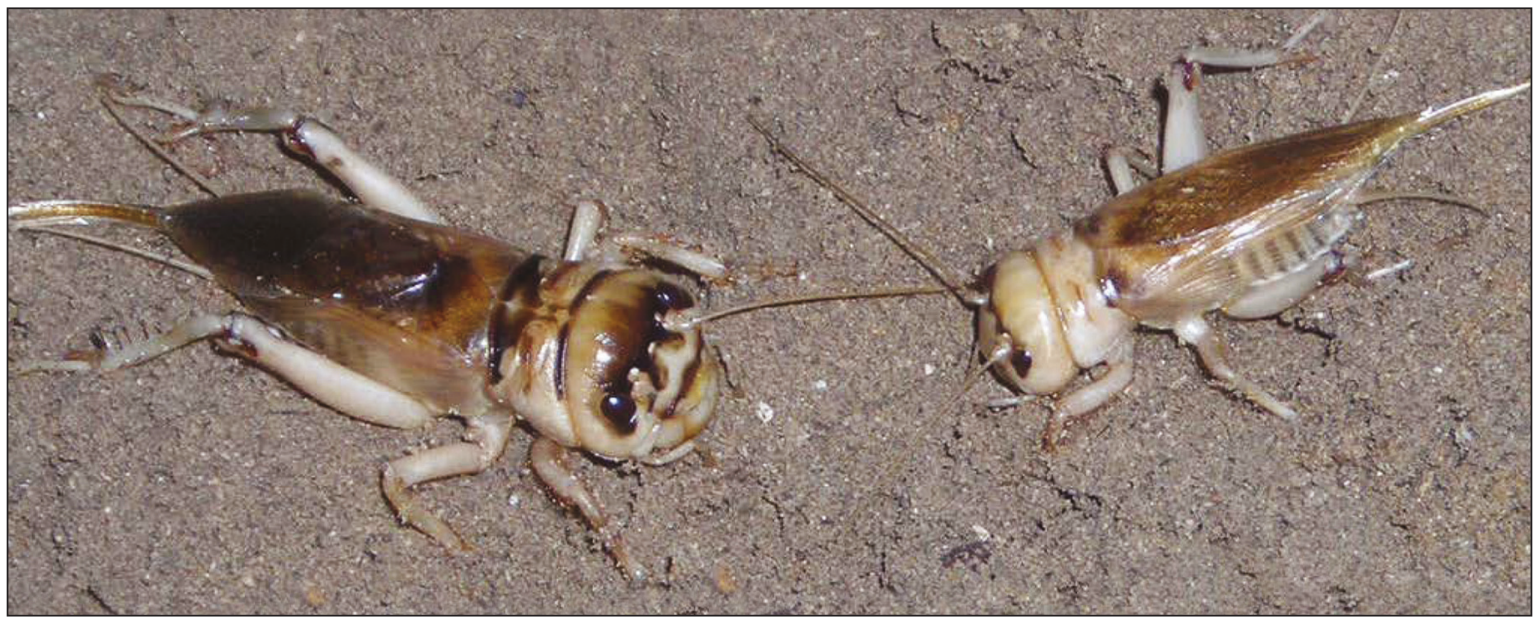

Figure 1. Brachytrupes megacephalus: male on the left, female on the right.

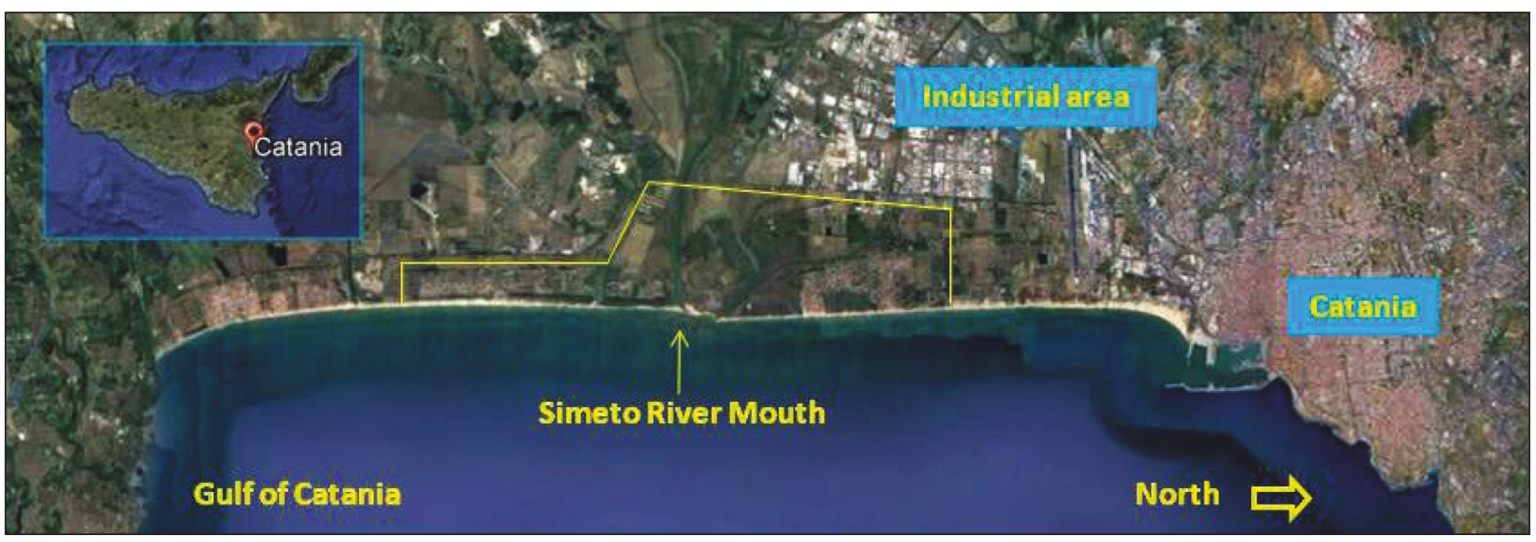

Figure 2. The "Oriented Natural Reserve of Simeto Oasis" is located 4 kilometers south of the city of Catania along the eastern coast of Sicily. The perimeter of the coastal part of the reserve where the study was conducted is highlighted: it extends for about 5 kilometers both northwards (north sector) and southwards (south sector) in relation to the Simeto mouth, with a maximum inland westward of about 2.5 kilometers from the sea. The sandy coastal areas along the whole Gulf of Catania (closed between the lava rocky prominences to the north and the limestone ones to the south) are due to the detrital transport of the Simeto river spread by the currents parallel to the coast (Di Stefano et al., 2013). 


\section{MATERIAL AND METHODS}

\section{Study area}

The Natural Reserve "Simeto Oasis" in which this research was carried out includes the area of the Simeto (the most important Sicilian watercourse) river's mouth and the Simeto river section, going up the river, until shortly after the confluence with the Dittaino River. The protected area, extending over 1800 hectares, was established by the Government of the Sicily Region in 1984 to stem the previous heavy anthropogenic tampering, to promote the restoration of the natural habitats and to increase the conditions for the resting and nesting of avifauna. In the context of Natura 2000 Network it is part of the Special Area of Conservation (SAC), ITA 0700001 "Mouth of the Simeto river and Gornalunga Lake" and of the Special Protection Area (SPA) ITA 070029, "Biviere di Lentini, intermediate section of the Simeto river and area in front of the mouth". The Reserve is important as one of the few Italian nesting sites of the anatid Ferruginous duck, $A y$ thya nyroca (Güldenstädt, 1770), and an area where it has been successfully reintroduced firstly in Sicily the Purple swamphens, Porphirio porphirio (Linnaeus, 1758) (Ientile \& Andreotti, 2003); also the sandy beaches of the reserve is back to being important for the nesting of the sea turtle, Caretta caretta (Linnaeus, 1758) (Torrisi, 2019); the reserve hosts a rich entomological psammic fauna (Petralia, 2002) and, among this, the $B$. megacephalus object of this study.

The characteristics and biodiversity of the reserve have been described by Ronsisvalle (1978), Costa et al. (1982), Caltabiano et al. (1984), Brullo et al. (1988), Ciaccio \& Priolo (1997), D’Ambra et al. (2002), Van der Sluis \& Pedroli (2003), Ientile \& Andreotti (2003).

In addressing the study of the state of $B$. megacephalus within the reserve, it is necessary to keep in mind the changes undergone by the entire area of the mouth of the Simeto, in particular during the XX century, which have modified its original naturalness characterized by dune fields that extended continuously along the entire Gulf of Catania (D’Arrigo, 1929) (Fig. 3). In the first decades of the century in the marshy areas, reclamation and hydraulic improvement interventions were started in the framework of the legislation of the time (L. 24 dicembre 1928 n. 3134) (Vagliasindi, 1933). From the 1940 s, the agrarian reform created the conditions (L. 2 gennaio 1940, n. 1) that gave rise to the planting of forage crops (now partly abandoned), vineyards, citrus groves and coastal windbreak woods to protect from the sea. Barriers upstream of the river, starting from the $1950 \mathrm{~s}$, have altered the natural transport of debris (Amore e Giuffrida, 1985), causing the dramatic retreat of the coastline along the entire Gulf of Catania (Longhitano \& Colella, 2007) and in particular of the beaches of the reserve (Di Stefano et al., 2013). In the second half of the past century, the natural evolution of the Simeto mouth (D'Arrigo, 1950) was superimposed on a rectification of the terminal stretch of the river related to anthropogenic factors (D’Arrigo, 1949), which isolated the ancient terminal meander (today an important wetland where the Purple swamphens nests). To all this was added an anarchic and massive urbanization which, from the second half of the 1950s, involved the construction of thousands of residential buildings (with annexed gardens) (Fig. 4) - whose demolition has often been requested (Salviamo il Paesaggio, 2012) - asphalted roads, vehicular traffic, with a consequent further drastic reduction of natural sandy surfaces estimated at around $10 \%$ of the original extension (Longhitano \& Colella, 2007). All conditions that in the second half of the 1970s sparked the debate on the need to move towards the recovery of the area (La Greca, 1977), a debate that in 1984 led to the establishment of the reserve with the aim, although within a framework of strong anthropization (Fig. 5), to protect and recover the residual naturalness and its potential.

We have considered the reserve sector highlighted in Fig. 3 as the sample area in which to carry out systematic surveys even in the future, useful to following the evolution of the animals' activity during the mating period. This is the portion of the reserve that is least affected by anthropogenic pressure, thus lending itself better also for future investigations.

\section{Methods}

We carried out the field study from March 1st to June 30th 2019 in particular during the reproductive period of the species. To detect the presence of individuals, non-invasive methods have been 

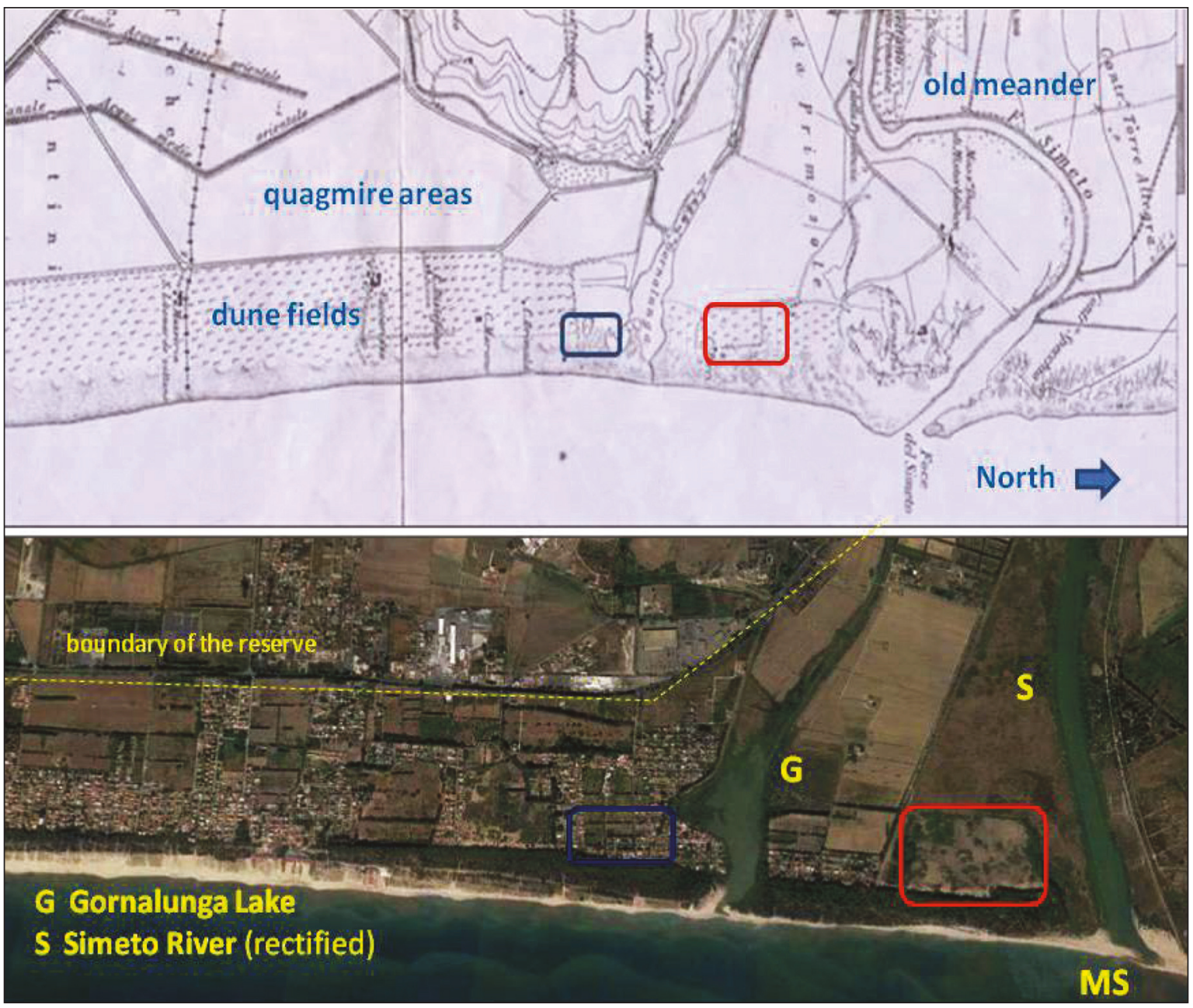

Figure 3. Above, part of the coast south of the Simeto (S) at the beginning of the 20th century: the coastal dune field is highlighted, which extended continuously along all the approximately 20 kilometers of the Catania coast up to the gates of Catania (D'Arrigo, 1929). Below, the same sector today with the rectification of the final stretch of the mouth of the Simeto (MS). The border of the current reserve is shown in dotted lines. The blue box is detailed in Fig. 4; the red box delimits the sample area indicated by A in Fig. 10.

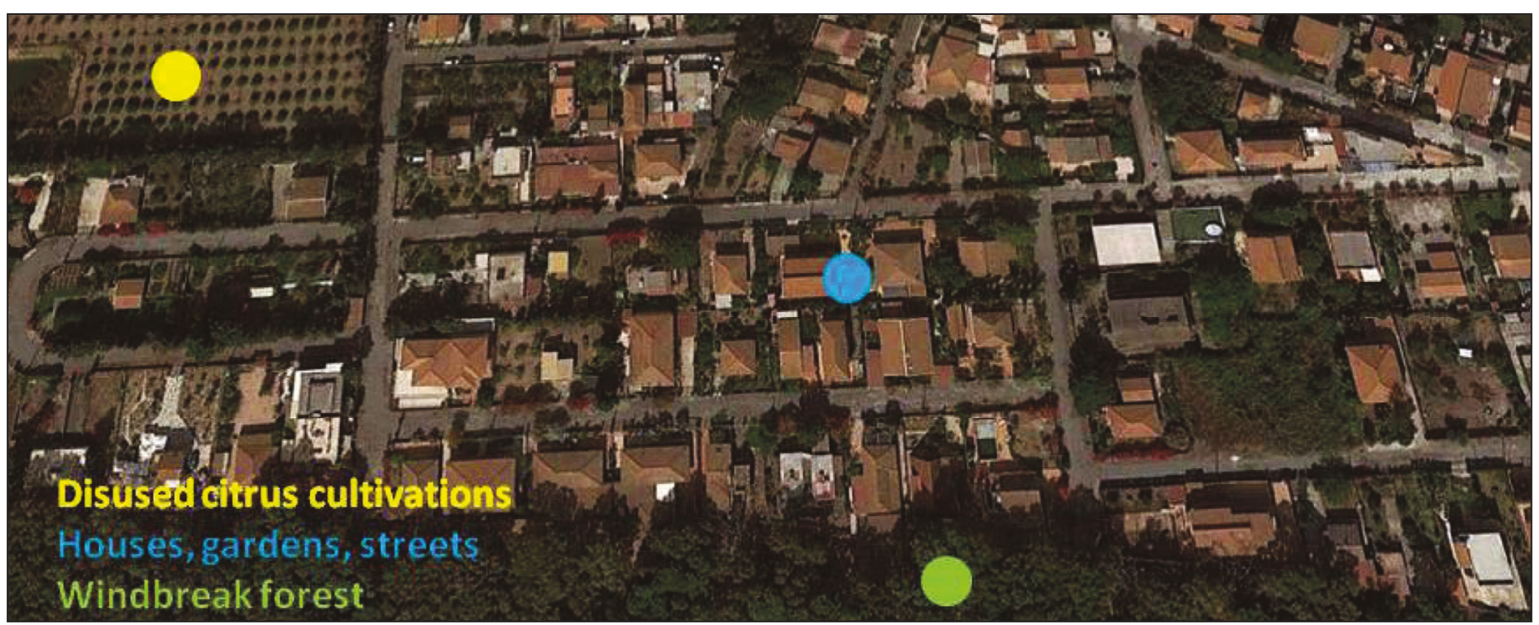

Figure 4. Particular features of the transformation of the reserve territory into urbanized areas (see Fig. 3). 


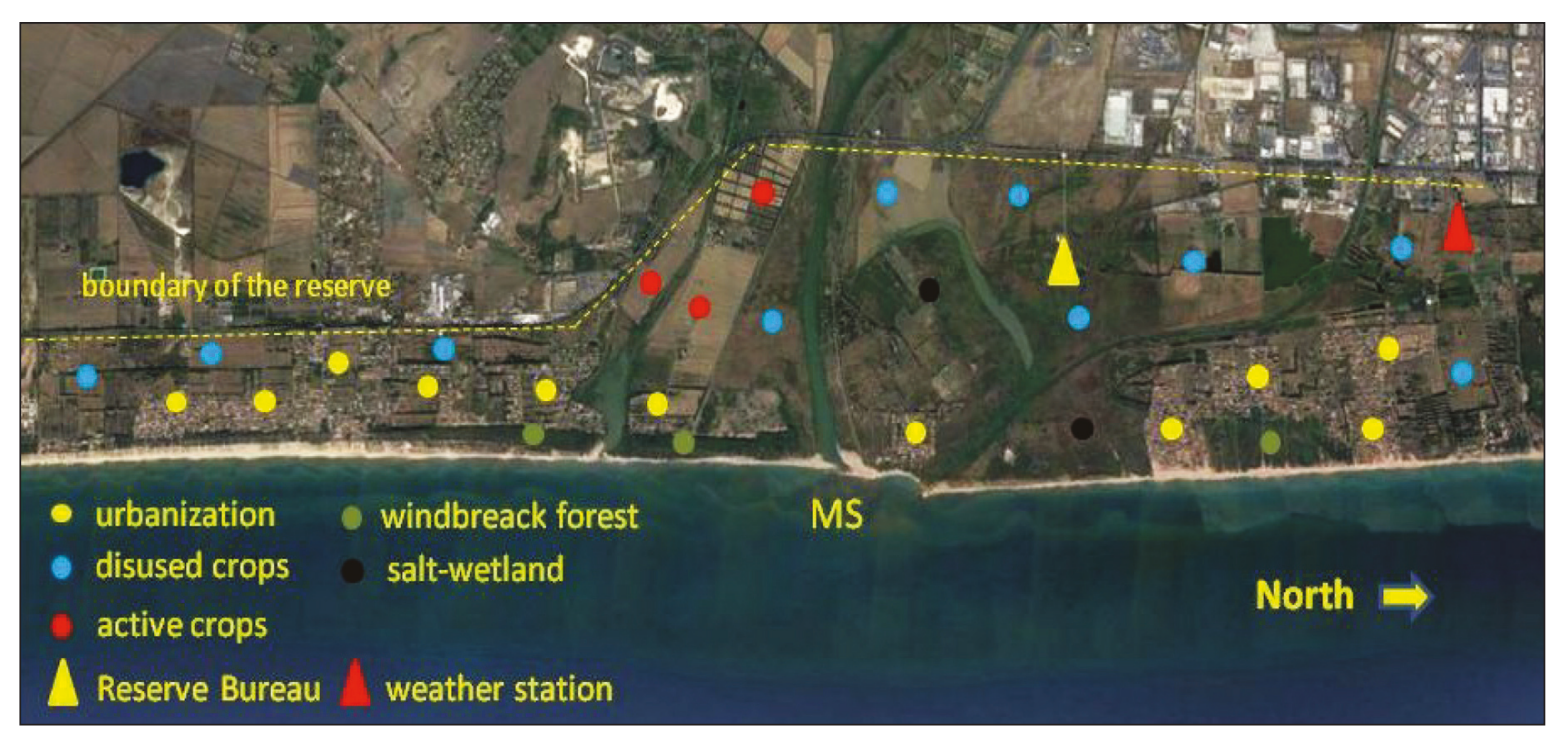

Figure 5. Analytical general main features of the anthropic presence in the Reserve. MS indicate the mouth of the Simeto river.

used to not harm the population. We based on three different indicators: a) the tunnels entrance (measuring the larger and smaller diameter) where animals live; b) the sandy "mounds" (estimating their maximum height and base diameters) resulting from the animals digging activity following the expulsion of sand from the inside; c) the stridulations produced by the males to attract the females. For each survey were noted the GPS point (with a Garmin eTrex GPS10), the dates and the corresponding times for the subsequent information processing. The position of each "mound" or tunnel mouth has been marked (in loco) with a numbered mark.

We also made use of the testimonies of residents of the protected area who told us that they saw (confirming it through the photos of $B$. megacephaus shown by us) or heard the stridulations produced by males.

\section{Climatic conditions}

For macroclimatic data we used the measurements taken by the "S. Francesco La Rena" weather station (coordinates UTM 4144073-506089, Fig. 5) of the Sicilian Agrometeorological Information Service which provided the hourly values of air temperature, humidity, rainfall, wind speed and direction, solar radiation. In addition, some microclimatic parameters (soil surface temperature, temperature at $5 \mathrm{~cm}, 15 \mathrm{~cm}$ and $40 \mathrm{~cm}$ of depth) were also measured in correspondence to the burrows entrances and the "mounds" (that were also photographed). For microclimatic measurements we used a Thermo-hygrometer UR 200 XS Instruments with surface and depth probes.

\section{RESULTS}

The observations started on March 1, 2019 and ended with the appearance of the first juvenile, observed in surface activity on June 24 at 21.23.

We detected 133 mounds, produced by the digging activity of adults (Fig. 6), some juvenile (Fig. 7), and 23 holes (Fig. 8) that indicate on the surface the entrance to the tunnels dug in the sand by adults; in 7 listening points we detected the stridulations emitted by the males to recall the females and lastly we made use of some testimonies of local people who reported seeing or hearing the animals in the gardens of their homes.

By georeferencing all the points where traces of the animals were found, we reconstructed a map of the presence of the species in the reserve: Fig. 9 summarizes the situation detected during these investigations.

During the spring activity phase of the animals (Fig. 10) the mean air temperature was maintained between $12{ }^{\circ} \mathrm{C}$ and $15^{\circ} \mathrm{C}$ with a humidity only exceptionally below $50 \%$. 

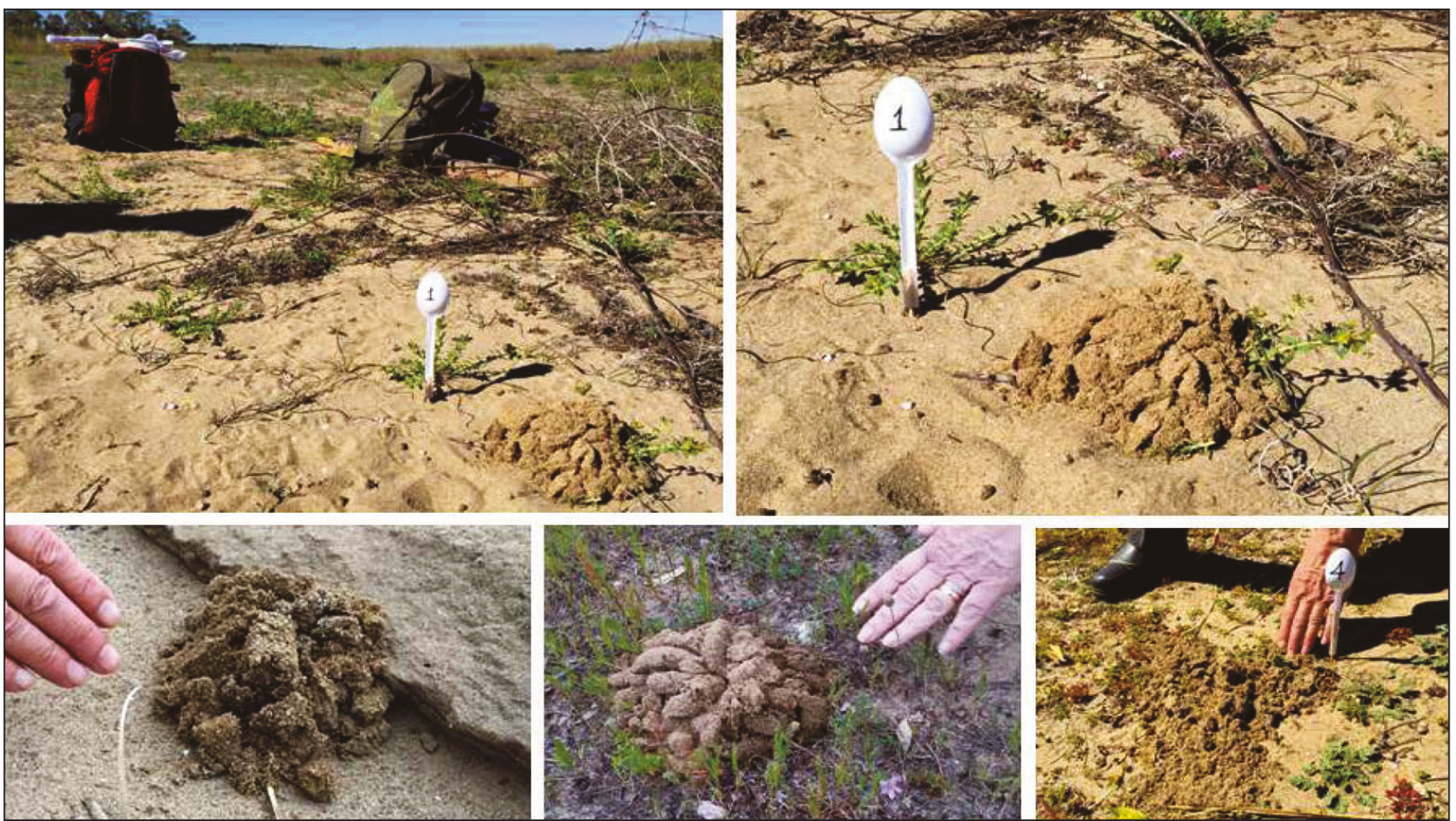

Figure 6. Various shapes of adults' mounds. The one tagged with n.1 was the first observed, on March 15th: nearby are present Euphorbia terracina L. and Cyperus capitatus Vand. Close to n. 4 there are specimens of Erodium laciniatum (Cav.) Willd., Rumex bucephalophorus L. and Arisarum vulgare O. Trag. Tozz.

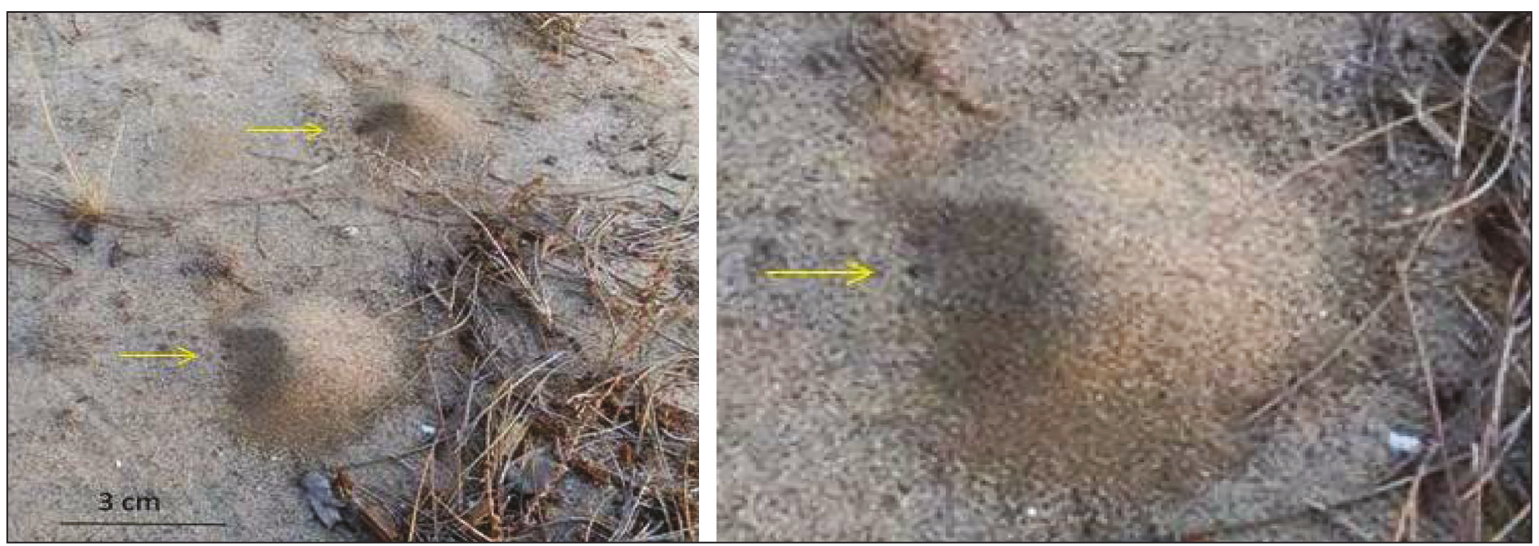

Figure 7. Nymph mounds. Photo zoom of the one on the bottom left (about $2 \mathrm{~cm}$ high). In both mounds it is possible to localize the mouth of the tunnels from which the sand was expelled.

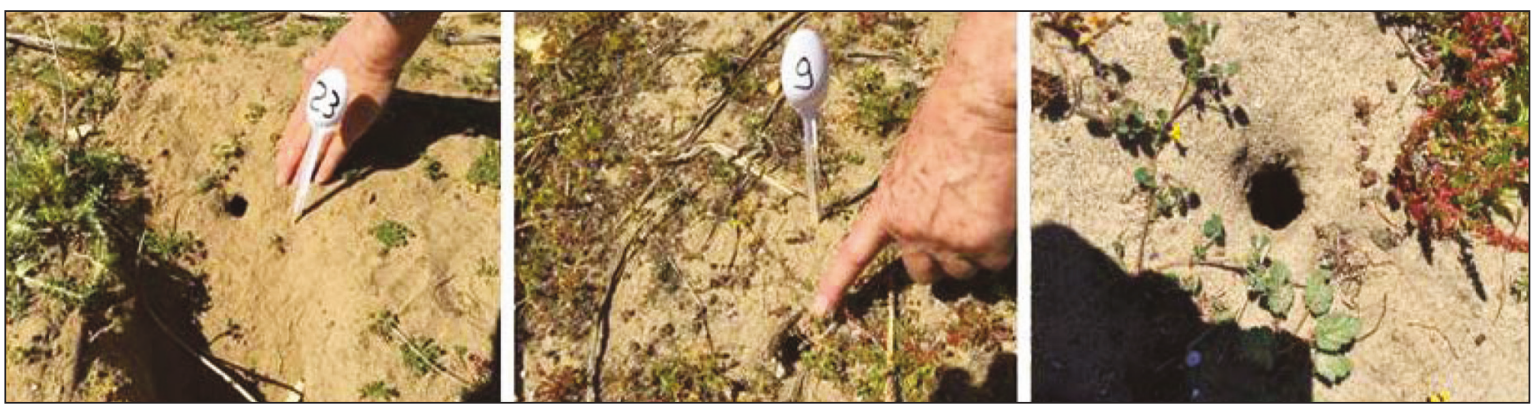

Figure 8. Different aspects of the tunnels entrance on the surface. In the right photo around the hole (clockwise from left up) plants of Medicago tornata (L.), Miller, Rumex bucephalophorus L., Erodium laciniatum (Cav.) Wild. 


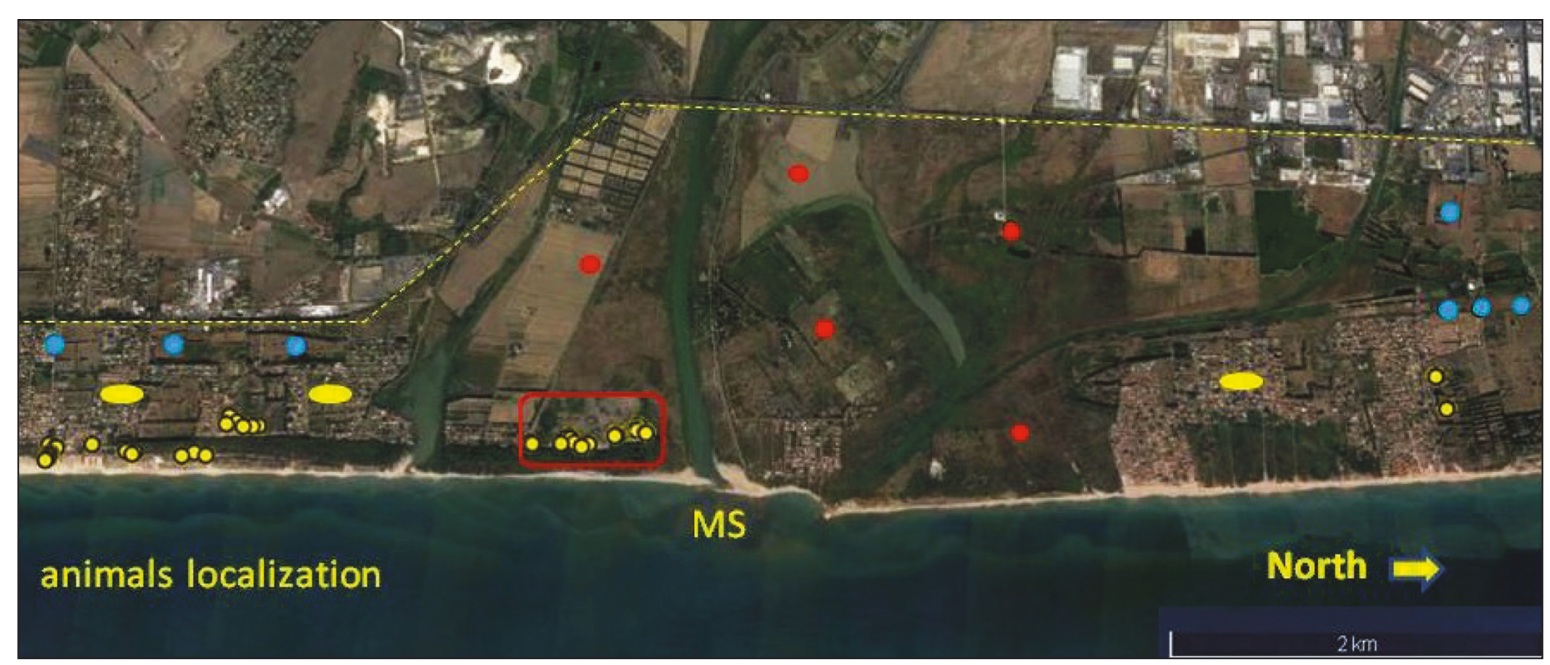

Figure 9. Localization of B. megacephalus inside the Reserve: the yellow circles represent the findings of cones or holes; the blue circles represent the listening points; the red circles represent the areas where we have not detected traces or stridulations; the yellow ovals indicate areas where we have had evidence of stridulation from the local people's information; the observations made in the sample area bordered in red will be commented in detail later in the text.

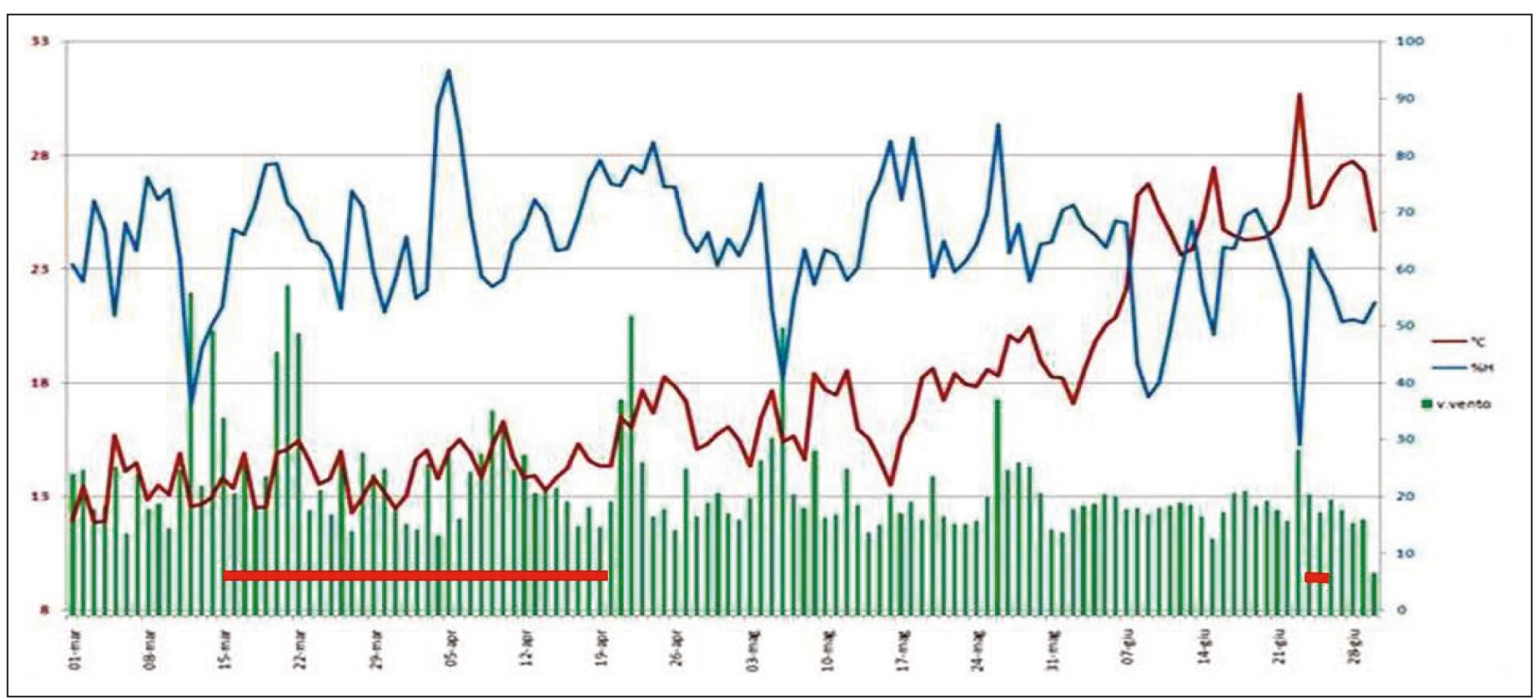

Figure 10. Climate trend in the investigation period. The rainfall values have been omitted as they are negligible. The red bar on the left covers the period of reproductive activity of the animals, the one on the right indicates the day when the juvenile activity was observed (see Fig. 16).

The trend of the traces observed in the activity of the animals, despite the discontinuity of the surveys, is shown in Fig. 11. However, there is an evolution that fluctuates significantly between the beginning (March 15) and the last day of activity (April 15): after the start of the animal activity there was a decline that may have been influenced by particular conditions of greater windiness between 20 and 22 March (as is evident in Fig. 10) which probably precludes attracting the females for mating, an action which is followed by the excavation to close the den and therefore the formation of mounds (as has been ascertained in previous research by Caltabiano et al., 1983).

It therefore seems that a wind level over $2 \mathrm{~ms}$ represents a limit beyond which the sound call is interrupted as it is obviously ineffective: this has been clearly highlighted not only in this species but 


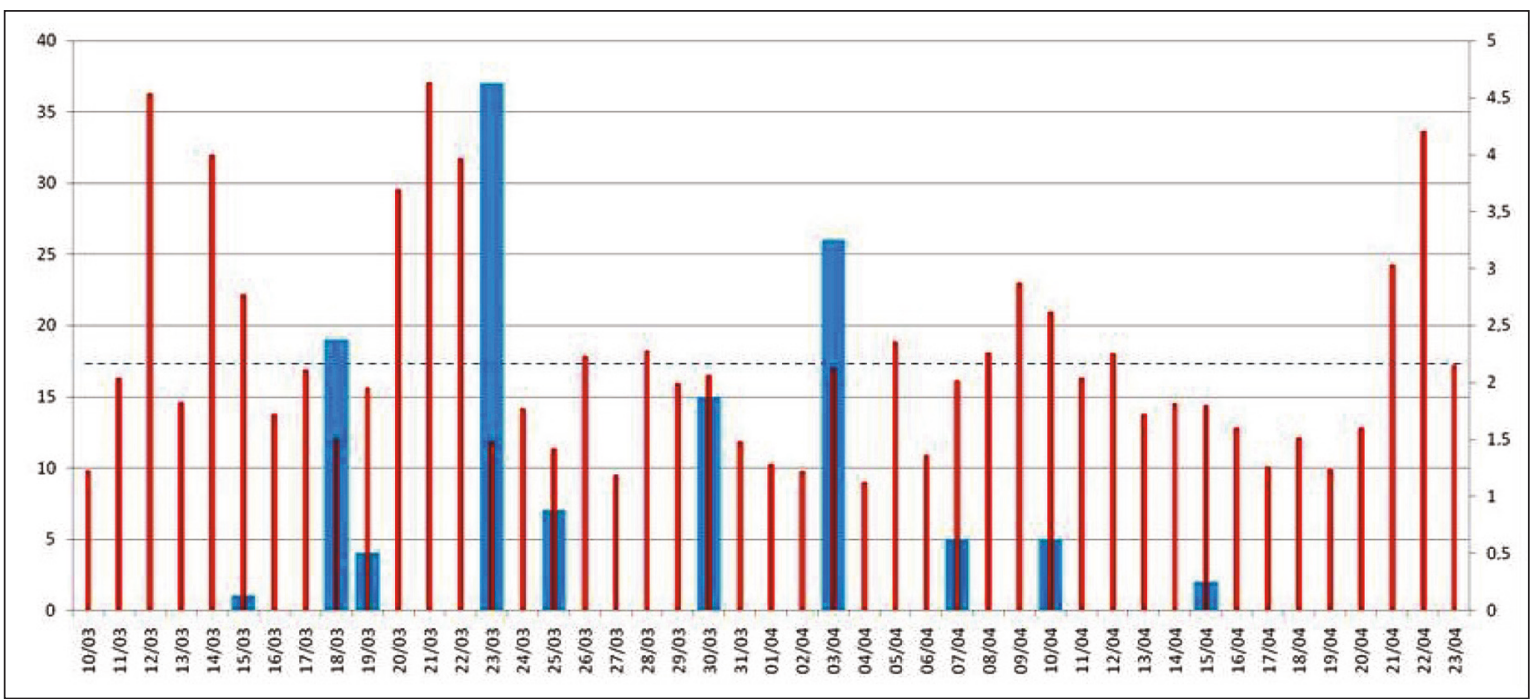

Figure 11. In blue the number of cones and holes counted (left y axis) during the surveys (x axis) in relation to the mean daily wind speed in ms (right y axis) in the reproductive period.

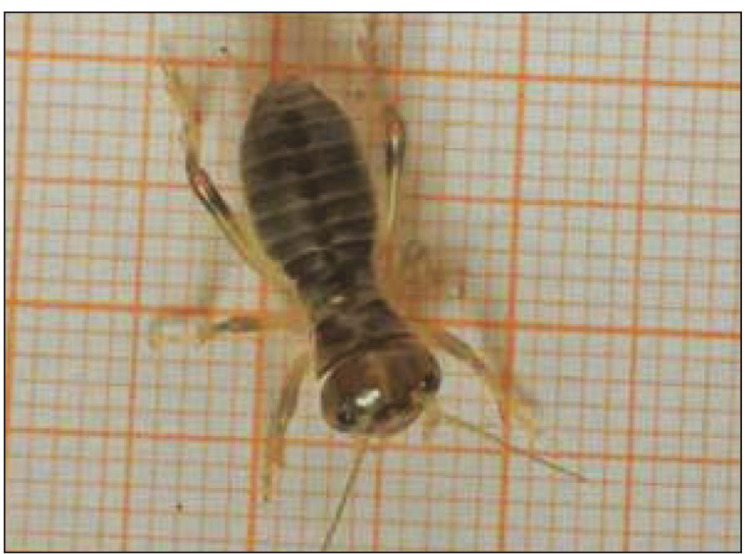

Figure 12. The young of B. megacephalus observed in activity on tha surface, photographed on graph paper.

also in B. membranaceus (Costa et al., 1984) under analogous conditions.

The activity of adult animals (Fig. 10) definitively ceased with the beginning of the phase of progressive increasing temperature, that occurs during eggs incubation and then the hatching: we ob- served a juvenile active on the surface (Fig. 12) when the mean temperature was around $25^{\circ} \mathrm{C}$.

We have adopted as the sample area the one shown in Fig. 9, for a more detailed analysis and also in view of future long-term surveys, as it is less subjected to previous and current anthropogenic interference. We have conducted observations every 2-5 days, in the mating period, from the beginning of March until the end of April. The results relating to the 88 traces detected inside it (mounds and holes) are highlighted in Fig. 13 while in Fig. 14 are illustrated some aspects of the habitat in which the animals resulted present.

We have evaluated the sizes of the mounds by considering their elliptical base and estimated their diameters and height, finally calculating their volume: in Table 1 these measurements are summarized. These, however, represent only an approximate assessment of the amount of sand that is moved by the digging activity of animals, even if indicative and useful for possible comparisons with other similar studies.

\begin{tabular}{|l|c|c|c|c|}
\hline Mounds' estimated size & $\mathrm{DM} \mathrm{cm}(\mathrm{sd})$ & $\mathrm{dm} \mathrm{cm}(\mathrm{sd})$ & $\mathrm{h} \mathrm{cm}(\mathrm{sd})$ & $\mathrm{V} \mathrm{cm}^{3}(\mathrm{sd})$ \\
\hline Adults $(64$ mounds) & $21.29(6.72)$ & $16.94(4.71)$ & $6.01(1.82)$ & $645.40(462.20)$ \\
\hline Juveniles (4 mounds) & $4.9(3.10)$ & $3.8(2.10)$ & $1.9(0.60)$ & $13.2(13.0)$ \\
\hline
\end{tabular}

Table 1. Size of the mounds. 


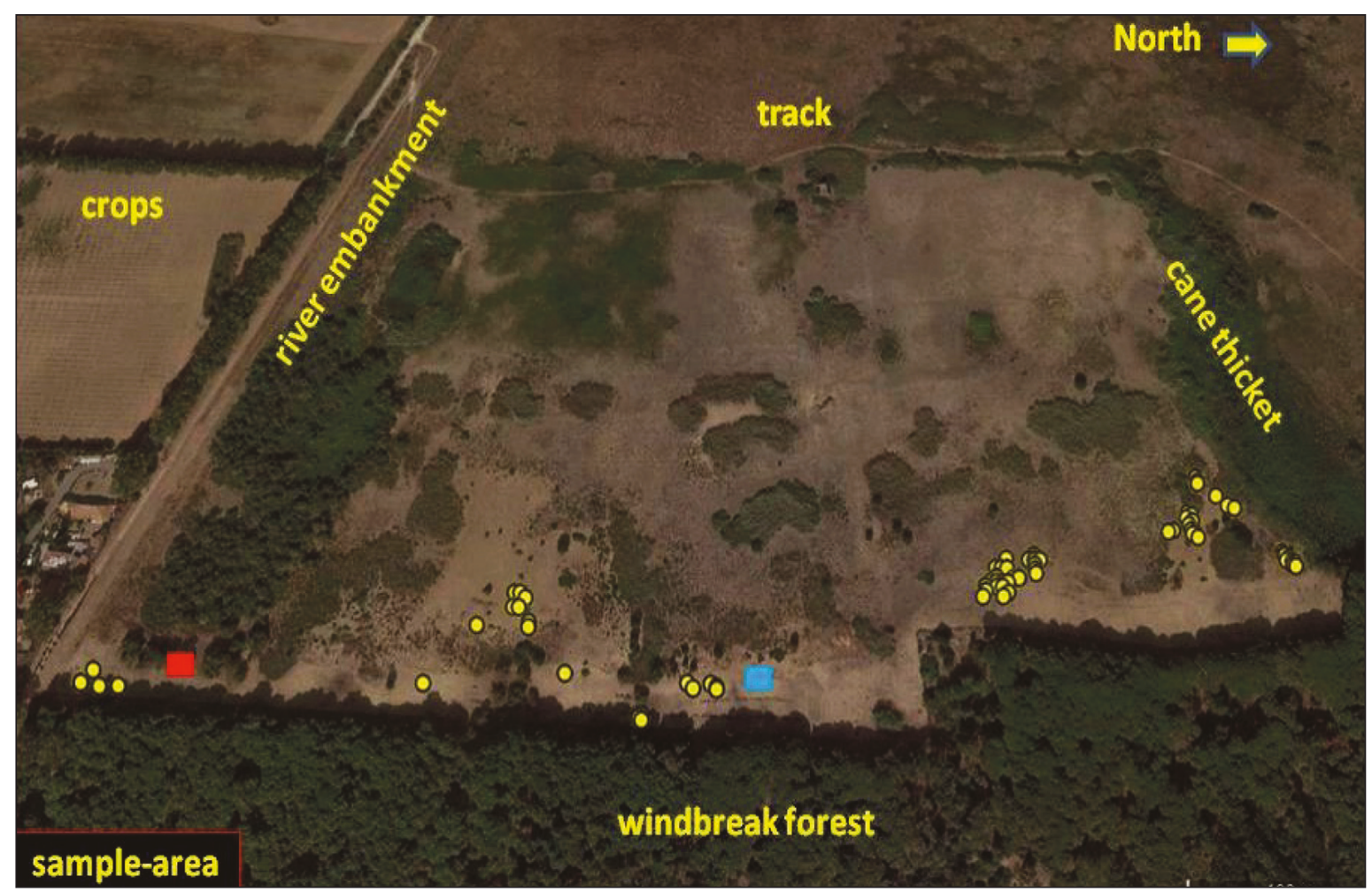

Figure 13. Aspect and boundaries of the Reserve area chosen as sample area (about 200 hectares) between the river bank (to the south), the reeds (to the north), the track and the windbreak wood (respectively to the west and east). The yellow circles indicate the location (gps) of the traces detected. Inside the area there are isolated reeds (Arundo donax L.), mastic patches (Pistacia lentiscus L.), residual areas with Ononis natrix L. subsp. ramosissima (Desf.) Batt. On the left, parallel to the embankment, a grove of Acacia saligna (Labill.). In Fig. 14 there is a photographic view of the areas marked here in red and blue.
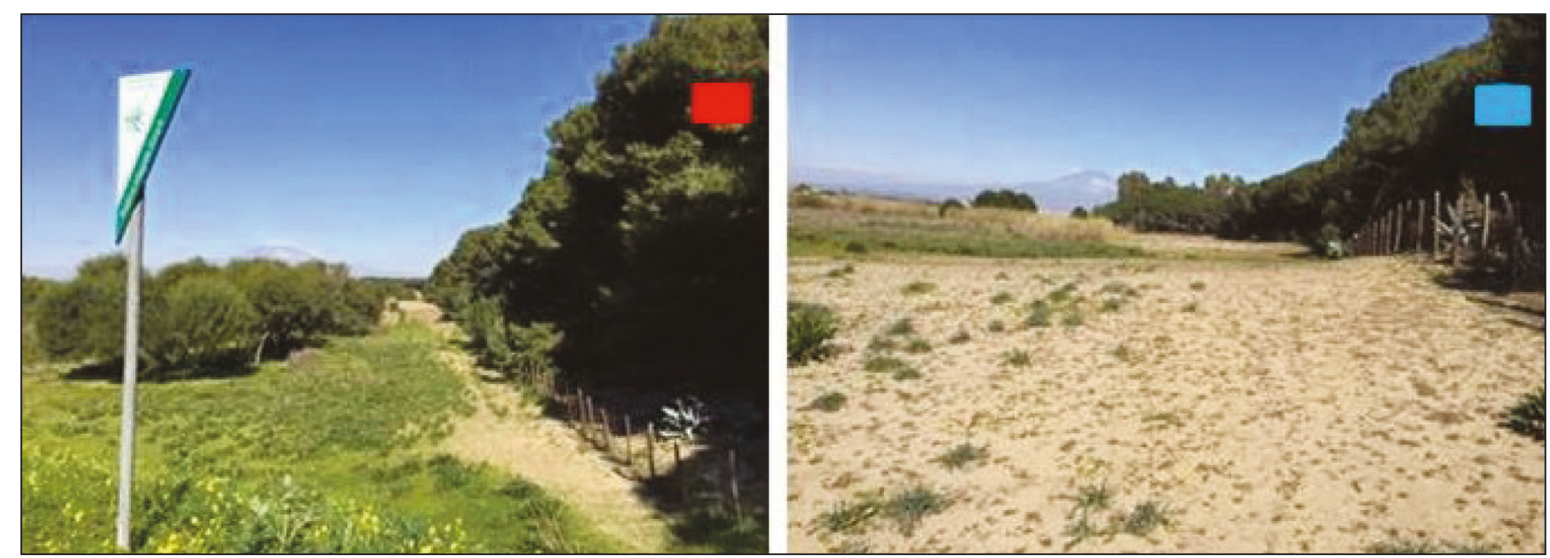

Figure 14. Aspects of the sandy strips (corresponding to those cited in the previous Fig. 10 with the red and blue circles) in which traces of the presence of the animals have been localized: the favourable habitat goes from a few meters (photo on the left) up to about 100 meters from the edge of the windbreak wood (photo on the right); in this second case it is a retro-dune environment with mostly therophytic vegetation with annual plants such as those mentioned in the previous figures while the few visible perennial species are Pancratium maritimum L., Arisarum vulgare O.Targ. Tozz. and on the left edge Charybdis pancration (Steinh.): it is an habitat of UE interest "2230 - Dunes with meadows of Malcolmietalia". There are also large formations of Asphodelus ramosus L. In the photo on the left we can clearly distinguish the prairie dominated by Charybdis pancration (Steinh.), which is not colonized by B. megacephalus, as well as a grove of Acacia saligna and the whole ground of the windbreak wood. The profile of Etna can be seen in the background of the photos. 


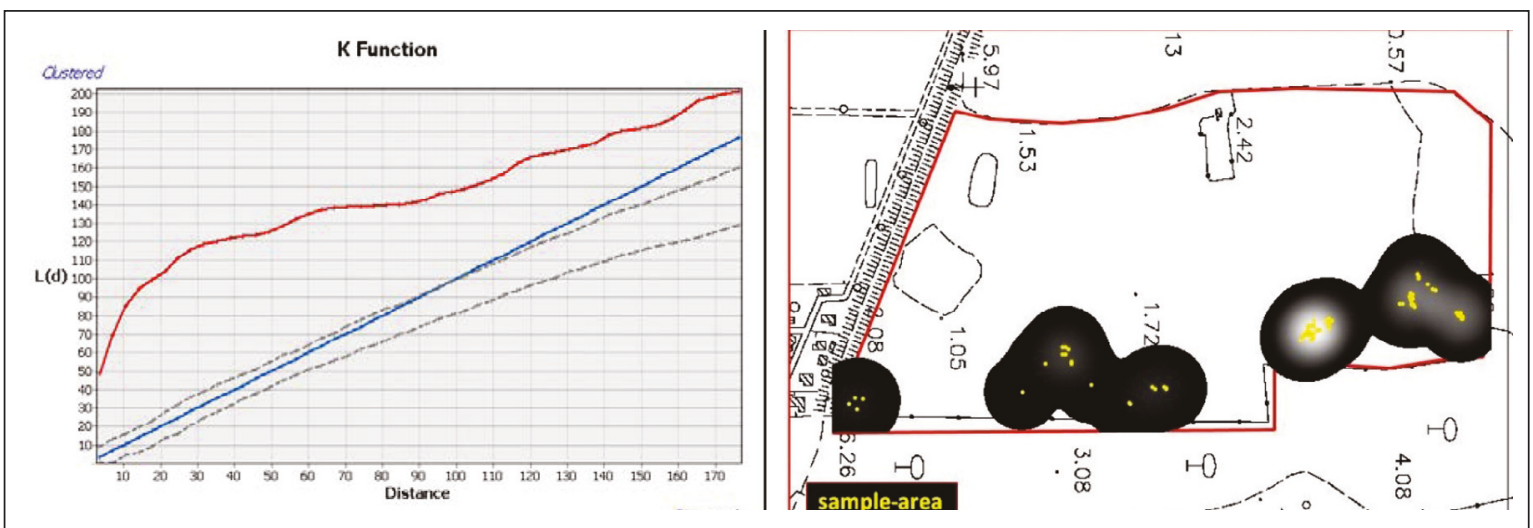

Figure 15. Spatial analysis of animals within the study area with Ripley's K-test. Lairs result clearly clustered in the more idoneous habitat, that is, the back dune with therophytic vegetation characterized by annual plants.

The entrance holes of the measured tunnels were generally slightly elliptical with the larger and smaller diameter respectively of 2.70 and $2.46 \mathrm{~cm}$ (sd 0.62 and $0.50 \mathrm{~cm}$ ).

To confirm the apparent aggregation of the found lairs, a spatial cluster statistical analysis was performed on the mounds and lair's holes counted in the period 15 March-15 April, in order to assess their spatial distribution pattern in the samplingarea; Ripley's K-function test (in Farina, 2001) was used as calculation index. Ripley's K-test compares, within a certain area, real point's distances with expected point's distances, determining if a pattern feature is clustered at multiple different distances. Along the resulting observed $\mathrm{K}$ curve ( $\mathrm{K}$ value is then linearised versus the distance, Ld) (Fig. 15), when the observed $\mathrm{K}$ value is larger than the ex- pected $\mathrm{K}$ value for a particular distance, the distribution is more clustered than a random distribution at that distance; when the observed $\mathrm{K}$ value is smaller than the expected $\mathrm{K}$, the distribution is more dispersed than a random distribution at that distance. According the resulting $\mathrm{K}(\mathrm{Ld})$ function we can observe that for all the distances the observed $\mathrm{K}$ values are larger than expected $\mathrm{K}$ values, so we can conclude (with a statistical significance of $99.9 \%$ ) that the cones and lair's holes, within our study area, are clustered both at smaller and larger distances.

The macroclimatic conditions of the Reserve are represented in Fig. 16 which also illustrates how the species is present in very different climatic habitats.

As regards the microclimatic soil conditions in the vicinity of the burrows, Table 2 describes the

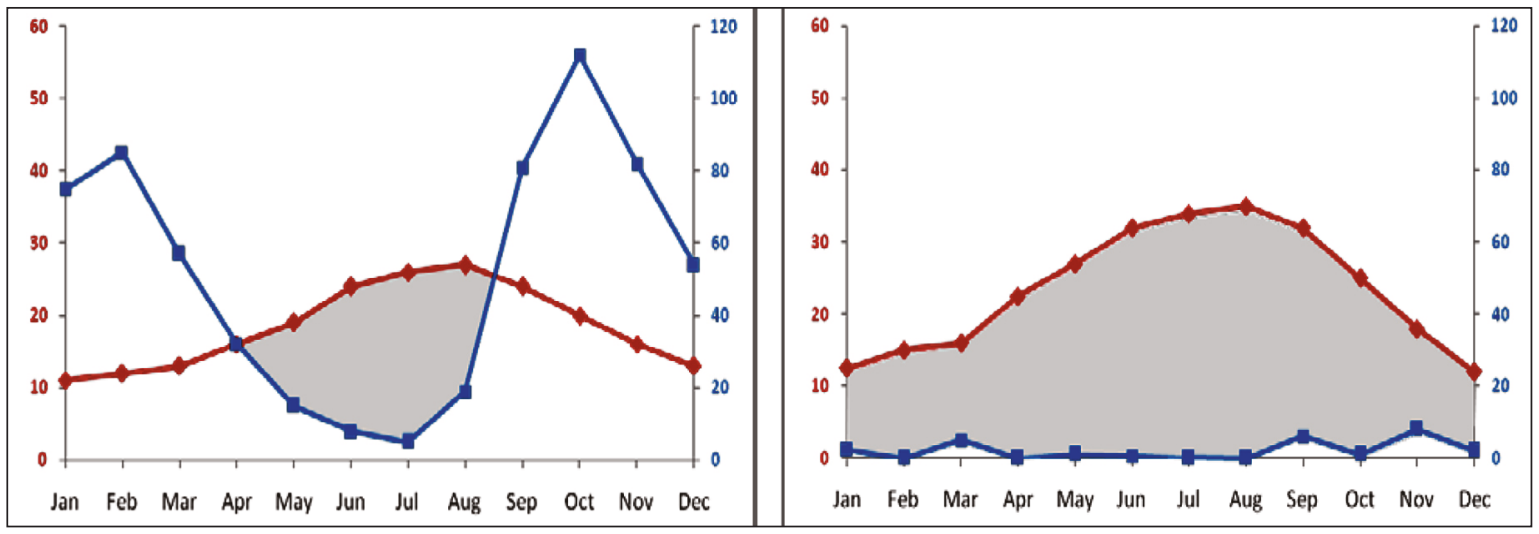

Figure 16. Comparison between the climograms of the Simeto Oasis Reserve (left) and the Tozeur region (Algeria, from Lakhdari, 2015) where the species is present. 


\begin{tabular}{|c|c|c|c|c|c|c|c|c|c|c|c|}
\hline DATES & HOURS & SUR. & -5 & -15 & -40 & DATES & HOURS & SUR. & -5 & -15 & -40 \\
\hline $18 / 03 / 2019$ & 10:00:00 & 34.4 & 25.4 & 16.1 & 15,3 & $23 / 03 / 2019$ & $16: 08: 00$ & 32.1 & 31.9 & 23.2 & 18.2 \\
\hline $30 / 03 / 2019$ & 11:55:00 & 36.6 & 26.3 & 17,1 & 18.4 & $23 / 03 / 2019$ & $16: 17: 00$ & 31.3 & 31,2 & 23.1 & 18.2 \\
\hline $30 / 03 / 2019$ & $12: 10: 00$ & 41.9 & 28,1 & 17.4 & 20.2 & $23 / 03 / 2019$ & $16: 19: 00$ & 29,9 & 30,1 & 22,9 & 18,2 \\
\hline $30 / 03 / 2019$ & 12:15:00 & 45.8 & 34.9 & 18.5 & 19.4 & $23 / 03 / 2019$ & $16: 19: 00$ & 32.5 & 30.1 & 24.8 & 18.2 \\
\hline $30 / 03 / 2019$ & $12: 22: 00$ & 47.6 & 28.9 & 17.7 & 18.2 & $19 / 03 / 2019$ & $17: 02: 00$ & 17.3 & 18.2 & 19.3 & 17.9 \\
\hline $23 / 03 / 2019$ & $12: 40: 00$ & 43.9 & 33,9 & 22.2 & 20.2 & $19 / 03 / 2019$ & $17: 20: 00$ & 16.5 & 18.9 & 20.8 & 18.4 \\
\hline $18 / 03 / 2019$ & $12: 50: 00$ & 44.5 & 31.6 & 18.9 & 17.8 & $19 / 03 / 2019$ & $17: 25: 00$ & 16.4 & 18.6 & 18.6 & 18.5 \\
\hline $23 / 03 / 2019$ & $12: 53: 00$ & 45.9 & 33,9 & 22,2 & 20.2 & $19 / 03 / 2019$ & $18: 04: 53$ & 16.1 & 17.9 & 18.8 & 19.0 \\
\hline $23 / 03 / 2019$ & $12: 55: 00$ & 44.7 & 33.9 & 22,2 & 20.2 & $24 / 06 / 2019$ & $18: 59: 00$ & 34.3 & 40.3 & 37.2 & 29.1 \\
\hline $23 / 03 / 2019$ & 12:58:00 & 45.3 & 33.9 & 22.2 & 20.2 & & Av. & 25.2 & 26.4 & 23.2 & 19.5 \\
\hline $\begin{array}{l}03 / 04 / 2019 \\
05 / 06 / 2019\end{array}$ & $\begin{array}{l}13: 10: 00 \\
10: 05: 00\end{array}$ & $\begin{array}{l}44.5 \\
32.2\end{array}$ & $\begin{array}{l}37.7 \\
25.8\end{array}$ & $\begin{array}{l}19.8 \\
21.9\end{array}$ & $\begin{array}{l}19.1 \\
26.3\end{array}$ & & SD & 8.2 & 8.1 & 5.7 & 3.6 \\
\hline \multirow[t]{3}{*}{$05 / 06 / 2019$} & $12: 00: 00$ & 51.9 & 42.4 & 27.6 & 27.7 & & & & & & \\
\hline & Av. & 43.0 & 32.1 & 20.3 & 20.2 & & & & & & \\
\hline & SD & 5.5 & 5.0 & 3.1 & 3.3 & & & & & & \\
\hline
\end{tabular}

Table 2. Temperatures detected at different depths of the soil: morning on the left; afternoon on the right. The hours correspond to local daylight saving time (1 hour ahead of solar time).

temperature values we recorded on the surface and at various depths: the highest values are recorded in the morning hours; naturally going deeper by solar radiation. It can be observed that around the evening hours, in March and April, the surface temperature (the solar time values are shifted forward by one hour) significantly drops, creating the conditions for the animals to exit the tunnels to carry out the recall activity for mating while the individuals remain deep in the ground during the hottest hours: this is amply confirmed by the observations carried out in detail on the B. megacephalus population of the Capo Isola delle Correnti dunes in the extreme south of Sicily (Caltabiano et al., 1982), as well similar considerations have been reached on B. membranaceus, a closely related species, studied in Namibia (Costa et al., 1984): it is therefore the microclimatic conditions of the ground that determine the eco-ethology of our species and not the macroclimatic ones.

\section{DISCUSSION}

Regarding mounds, Lefebvre (1827) observed how the species "se fait parfois reconnaittre par une espèce de butte analogue à celles qui indiquent le passage des taupes" (in fact the similarity with the formations produced by moles is remarkable except for the considerably smaller size in our Orthoptera), description that Chopard (1943) evokes specifying how "l'entrée du terrier est boucheée pendant le iour et se reconnait par la présence d'un petit mounticle de sable". So the mounds are indeed a good trace of the presence of animals.

There is a difference between the "mounds" produced by adults compared to those of the early juvenile stages. In the first case (Fig. 6) the extrusion of the wet sand causes the formation of small cylinders of sand (as is often the case in moles) which fall overlapping: for this reason they are clearly recognizable especially in the early hours of the morning, since they subsequently become melted sand dehydrating by solar heating; instead in the "mounds" of the early juvenile stages, the more shallowness of the burrows and therefore the drier sand (due to the higher temperatures in June when they begin to appear) precludes the formation of cylinders (Fig. 7).

Another indicator of the activity of this, that can be observed on the surface of the sand, are the holes that correspond to the mouth of the tunnels where the individuals lodge: however, it must be considered that it is more often about dens abandoned by females as soon as they are attracted towards the dens of the males for mating, since the latter usually close them.

Hence "mounds" and holes represent a good non-invasive detector of the presence and especially of the location of animals, a methodology already used in a previous research in the Oriented Nature Reserve "Oasi Faunistica di Vendicari" (Petralia et alii, 2015) aimed to mapping the species. 
Concerning the stridulations these were described by Lefebvre as "....un roulement continu et soutenu, tellement fort et sonore, qu'il est susceptible d'être entendu à près d'un mille": undoubtedly they are audible at a considerable distance. From the standpoint of bio-acoustic, the stridulations of the species have been analyzed in their physical characteristics (Brizio, 2018) as well as for their importance about systematics of Orthoptera (Massa, 2013).

Therefore traces (mounds and holes) and stridulations reveal the existence of the species but differ in the effectiveness of the information, depending on the purpose of the monitoring. The first, mounds and holes, provide numerical information on the exact location of the animals which can be detected at any time of day and season; in the second case the information can be detected only when the stridulations are emitted, then they are linked to the seasonal phase (only in the reproductive period) and to the hour-time and weather conditions (in particular the windiness).

As regards the production of "mounds" in the period March-April, rather than having a Gaussian trend with an initial phase followed by an increase and then a decline, it could be characterized by two distinct phases, however strongly concealed by the climatic disturbance, especially from the windiness. This would seem to emerge by normalizing the moving average of the number of traces observed as shown in Fig. 17; the figure shows a comparison with similar data referring to the dunes of the "Macchia Foresta del Fiume Irminio" reserve (southern Sicily) (Inclimona, 2005-2006; Battaglia, 20072008): averaging the data results in a trend with two distinct peaks of activity. It should also be considered that in the researches of Lackdari et al. (2015b) a similar trend appears in the counts of mounds reported in their work. These considerations suggest the possibility that there is a bimodality in reproductive activity which, however, requires further and more evident confirmations, remaining at the moment a working hypothesis which is not without foundation.

The surveys under discussion have confirmed the presence of the species in most of the sandy territory of the Reserve in which the crops have been abandoned for the longest time, while it is absent where in all situations of heavily modified sandy soil no easily penetrated by individuals and not suitable for excavating tunnels. For similar
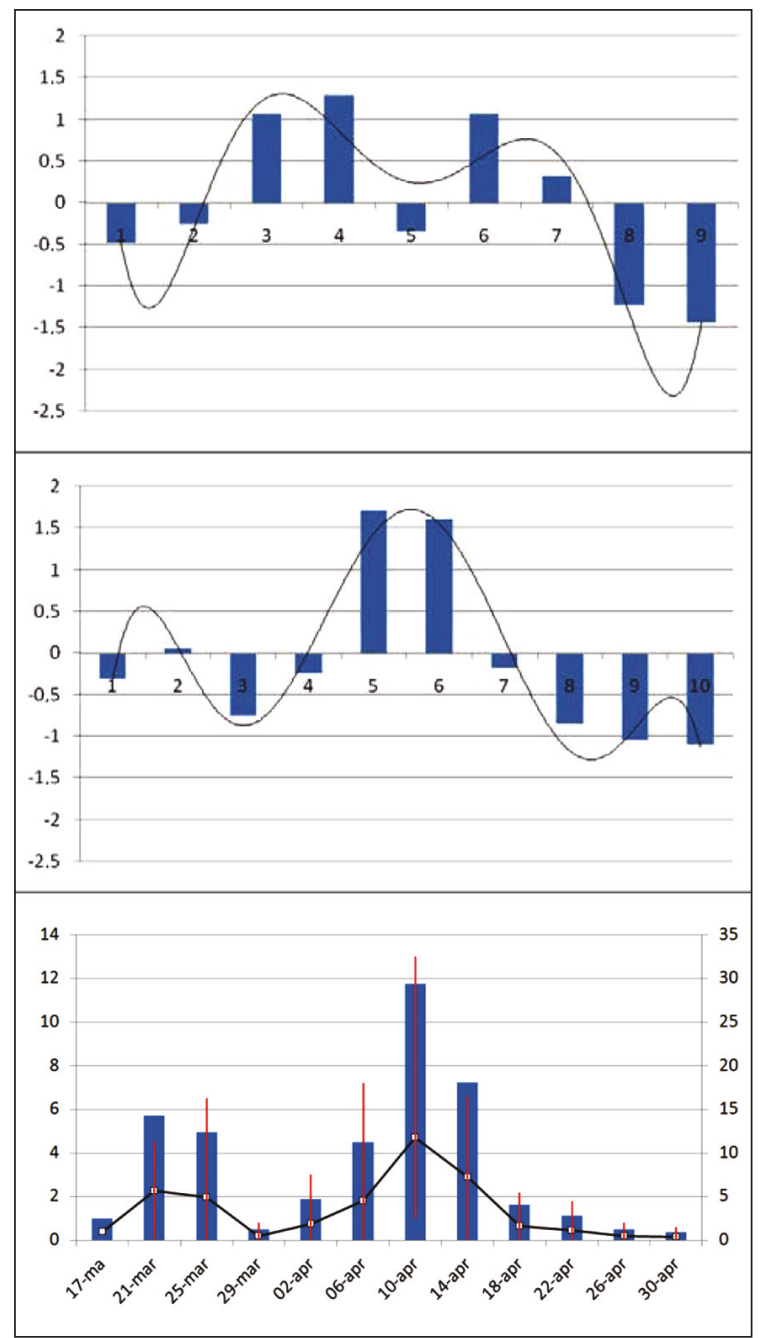

Figure 17. Comparison between the normalized moving averages of the number of $B$. megacephalus mounds observed in this research (top) and in the "Macchia Foresta del Fiume Irminio" reserve (Southern Sicily, from Conti et al., 2012) (middle). Below: overall average trend of the number of mounds recorded in the same reserves over the course of three survey campaigns in the reproductive period.

reasons, the animals are not present in the wet or brackish area.

Conversely the animals, even considering the drastic reduction of sandy surfaces (around 10\% compared to the original extension of the dune system as reported in the introduction paragraph), are present wherever the substrate allows their establishment, including the gardens of private houses where portions of sandy soil are present. Individuals are able to colonize microhabitats suitable even in particularly degraded and critical areas where their burrows are easily at risk of being destroyed (Fig. 18): which confirms their potential to expand in the reserve as 

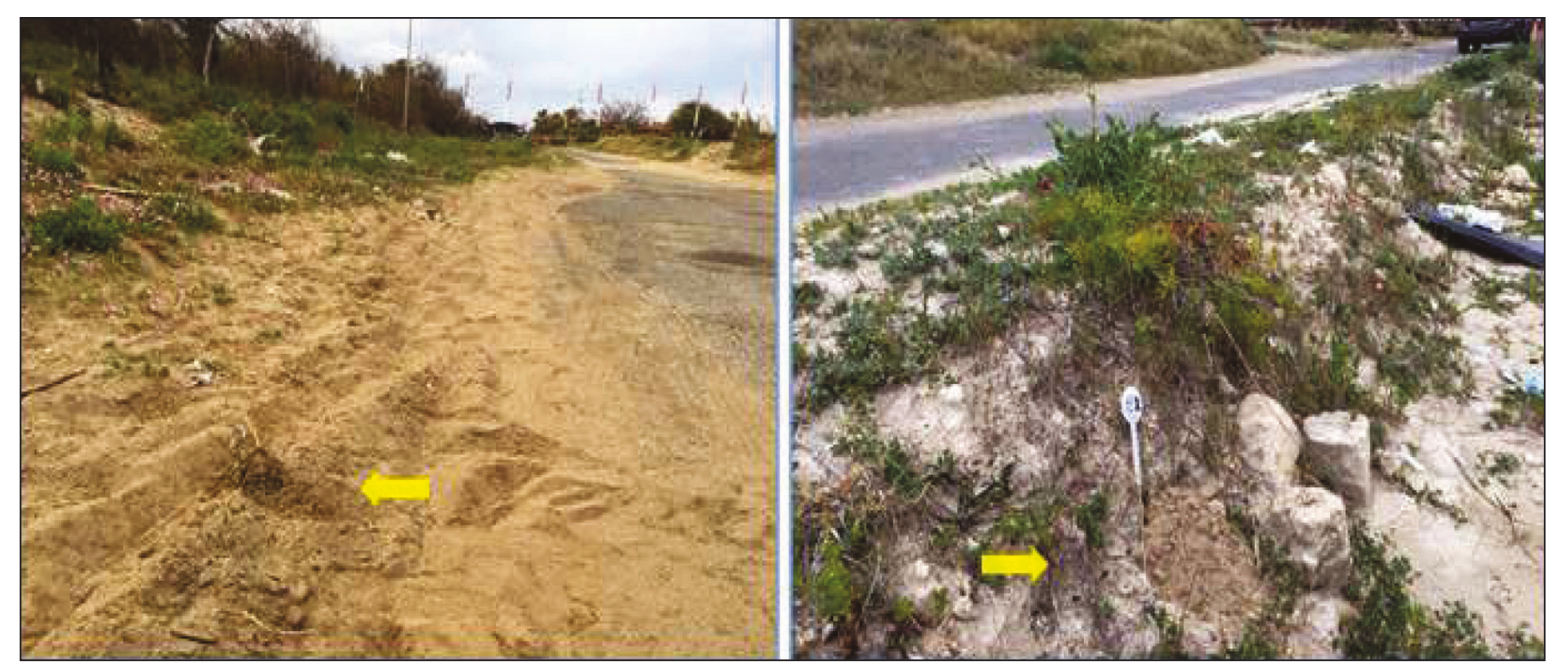

Figure 18. Presence of dens in critical position on the edge of paved roads that cross the reserve and which are normally traversed to reach homes, farms and for other needs.

long as they can maintain a close link with the favourable substrate.

Finally, it is interesting to underline how the attention for this species, or for others of the same genus, has different reasons.

Since its description and still today B. megacephalus is the subject of scientific research. But it has also been considered a pest causing damage to crops and for this reason, for many decades, it has been fought in particular in Sicily (where it is called "cicalone") and in Sardinia (Leonardi, 1901; Silvestri, 1939; Grandi, 1951; Zanardi, 1964).

Due to its rarefaction and with the increase of a new naturalistic sensitivity for the conservation of biodiversity in Europe, the species is now protected as a species of community interest.

At the same time, in those range areas where the species is widely diffused, the need to protect crops from the damage deriving from its presence, such as in Libya or Algeria (Lakhdari, 2015), still leads to applied forms of struggle against of it (Lakdari et al., 2015a, b, c, d) and similarly against other species of the same genus, as for $B$. membranaceus (Drury, 1770) (present from tropical Africa to the Transvaal) (Hill, 2008; Bunzli \& Buttiker, 1955) or for B. portentosus (Lichtenstein, 1796) in India, since long time (Ghosh, 1912).

Furthermore, historically, B. megacephlus has been cited as part of the food tradition of the inhabitants of the oases of southern Libya (Scortecci, 1960) as well as for the congeners $B$. membranaceus in southern Africa (Van Huis, 2003; Okeke et al., 2019), still studied as a food source even if its rarefaction is reported (Amadi \& Kiin-Kabari, 2016), B. orientalis (Burmeister, 1838) in India (Chakravorty et al., 2014) and B. membranaceus colosseus Saussure, 1899 in Madagascar (Van Itterbeeck et al., 2019).

\section{CONCLUSIONS}

A field monitoring in 2003 (Petralia et al., 2015) had highlighted the presence of $B$. megacephalus in the reserve while in other investigations its presence was found along the entire dune belt of the Gulf of Catania both south and north of the reserve (Maltese, 2002-2003), in the residual sandy areas no longer cultivated and also in the soil of some citrus groves.

The present research therefore confirms the significant presence of B. megacephalus in the reserve that in any case represents a territory in which appropriate actions are necessary to safeguard the species' habitat aimed at the conservation of the species itself, actions that consequently strengthen the function of protect biodiversity as a whole. The continuation of research on our species is therefore also desirable to further clarify the many and peculiar aspects of its biology, which already have in themselves a relevant scientific importance for increasing knowledge.

On the basis of the foregoing, some management measures are therefore suggested to support the conservation of the species: 
$a$ - prevent any further form of anthropogenic occupation of the territory in the reserve; $b$ - favour in every way the restoration and extension of the natural habitat of the species throughout the territory free or freed from anthropogenic presence; $c$ - encourage those who carry out any type of activity within the reserve to minimize interference on the eco-ethology of the species; $d$ - encourage homeowners to preserve the sandy portions of the annexed gardens to facilitate the permanence of the animals, in particular by excluding the use of toxic herbicides, further overbuilding, anarchic littering; $e$ - disseminate, in every ambit and by any means (in particular among the residents of the reserve), awareness of the importance of the species and knowledge on its biology and behavior also by setting up an exhibition section dedicated to this at the Reserve Information center; $f$-continue monitoring the state of the species to keep under control the evolution of its presence.

A protocol is proposed to follow the evolution of the species in the time and space, by foreseeing:

1 - annual monitoring in the sample area to be conducted from 1 March to 30 April with daily inspections (or at least every two days) and detection and counting of "mounds", in the morning when they are most clearly visible, noting their GPS position and tagging them in the field with a recognizable mark to avoid recounting;

2 - in parallel it can be useful to detect the stridulations in the evening hours on different listening points to be carried out around sunset, noting the time and position;

3 - repetition every 3 years of widespread detection of animal traces in the territory of the Reserve;

4 - plan an encouragement campaign for residents to report the presence of the species in the private areas of the Reserve.

It is important to highlight the significance of Brachytrupes megacephalus as a "flag species", as the benefit of protecting the species in fact falls not only upon all the other sabulicolous arthropods present (D'Ambra et al., 2002) but also on the whole habitats and fauna and flora species listed for the Site of Community Importance ITA070029 (part of Nature 2000 Network); this is also congruent with the actions indicated in the Management Plan of the Site "Simeto River", which also includes the monitoring of the invertebrate community (Provincia di Catania, 2010).

\section{ACKNOWLEDGMENTS}

We thank Prof. Carmelo Monaco and Prof. Pietro Minissale, professors of the Department of Biological, Geological and Environmental Sciences of the University of Catania, for the information relating to the geomorphological evolution of the coast of the Gulf of Catania and for the botanicalvegetal aspects respectively.

We also thank the Sicilian Agrometeorological Information Service of the Sicilian Region for providing the Reserve macroclimatic data.

\section{REFERENCES}

Amadi E.N. \& Kiin-Kabari D.B., 2016. Nutritional Composition and Microbiology of Some Edible Insects Commonly Eaten in Africa, Hurdles and Future Prospects: A Critical Review. Journal of Food: Microbiology, Safety \& Hygiene, 1: 1-107.

Amore C. \& Giuffrida E., 1985. L'influenza dell'interrimento dei bacini artificiali del F. Simeto sul litorale del Golfo di Catania. Bollettino della Società Geologica Italiana, 103: 731-753

Audinet-Serville M., 1839. Histoire naturelle des Insectes Orthoptères. Librairie Encyclopédique de Roret, Paris, pp. 323-326.

Brizio C., 2018. Bioacoustic evidence of two uncommon crickets from SW Sardinia, including an analysis of the song of Brachytrupes megacephalus (Lefèvre, 1827) (Orthoptera Gryllidae) in the ultrasonic range. Biodiversity Journal, 9: 135-142.

Brullo S., De Santis C., Furnari F., Longhitano N. \& Ronsisvalle G.A., 1988. La vegetazione dell'Oasi della Foce del Simeto (Sicilia Orientale). Braun-Blanquentia, 2: 165-188.

Bunzli G.H. \& Buttiker W.W., 1955. The control of the tobacco cricket (Brachytrupes membranaceus Drury) in Southern Rhodesia. Acta Tropica, 12: 252-260.

Caltabiano A.M., Costa G. \& Petralia A., 1979. Ricerche sulla locomozione negli Insetti. IV. Deambulazione, nuoto e scavo di Brachytrupes megacephalus (Lef.) (Orthoptera, Gryllidae). Animalia, 6: 71-79.

Caltabiano A.M., Costa G. \& Petralia A., 1982. Ricerche eco-etologiche sulla fauna delle dune costiere di Portopalo (Siracusa). IV: Biologia comportamentale di Brachytrupes megacephalus (Lef.) (Orthoptera, Gryllidae). Animalia, 9: 266-292.

Caltabiano A.M., Caruso S., Costa G., Di Franco F., Leonardi M.E. \& Petralia A., 1984. Ricerche eco-etologiche sulla fauna del sistema costiero dell'Oasi di protezione faunistica della foce del Simeto (CT). I. Biologia comportamentale di Scarites laevigatus F. 
(Coleoptera, Carabidae). Bollettino dell'Accademia Gioenia di Scienze Naturali in Catania, 17: 25-41.

Chakravorty J., Ghosh S., Jung C. \& Meyer-Rochow V.B., 2014. Nutritional composition of Chondacris rosea and Brachytrupes orientalis: two common insects used as food by tribes of Arunachal Pradesh, India. Journal of Asia-Pacific Entomology, 17: 407415.

Chopard L., 1943. Orthopteroides de l'Afrique du Nord. Faune de l'Empire Français I. Librairie Larose, Paris, $450 \mathrm{pp}$.

Cassar L. F. \& Galdies C., 2018. On the occurrence of Brachytrupes megacephalus (Lefebvre, 1827)(Orthoptera Gryllidae) on Lampedusa. Il Naturalista siciliano, 46: 17-22.

Ciaccio A. \& Priolo A., 1997. Avifauna della foce del Simeto, del lago di Lentini e delle zone umide adiacenti (Sicilia, Italia). Il Naturalista siciliano, 21: 309-413.

Conti E., Costa G., Petralia A. \& Petralia E., 2012. Ecoethology of Brachytrupes megacephalus (Orthoptera, Gryllidae), protected species in EU. Atti e Memorie dell'Ente Fauna Siciliana, 11: 51-56.

Costa G., Petralia A. \& Leonardi M.E., 1982). Ricerche sull'orientamento di Scarites laevigatus F. (Coleoptera, Carabidae). I. L'orientamento astronomico. Animalia, 9: 131-151.

Costa G., Leonardi M-E. \& Petralia A., 1984. Il comportamento riproduttivo del Grilllide Brachytrupes membranaceus (Drury). Bollettino delle sedute della Accademia Gioenia di Scienze Naturali in Catania, 17: $43-63$.

D’Ambra S., Di Martino V., Lizzio E., Longhitano S., Minissale P., Petralia A., Rannisi G. \& Spampinato G. - Servizio Parchi e Riserve della Provincia Regionale di Catania, 2002.

La Riserva Naturale Orientata Oasi del Simeto. Ed. Pangea, 350 pp.

D’Arrigo A., 1929. Regime della Plaia di Catania e migrazioni della foce del Simeto dal 1154 al 1928. Annali dei Lavori Pubblici, Roma, Libreria dello Stato, vol. 9: 783-808.

D'Arrigo A., 1949. La sistemazione della foce del Fiume Simeto. L'Ingegnere, 7: 757-760.

D’Arrigo A., 1950. Le migrazioni della Foce del Simeto dal 1154 al 1948. Bollettino dell'Accademia Gioenia di Scienze Naturali di Catania, 4: 313-324.

D’Arrigo A., 1953. Le migrazioni della foce del Si meto negli ultimi otto secoli. L'Universo, Rivista dell'Istituto Geografico Militare, 33: 595-607.

Di Stefano A., De Pietro R., Monaco C., Zanini A., 2013. Anthropogenic influence on coastal evolution: a case history from the Catania Gulf shoreline (eastern Sicily, Italy). Ocean \& Coastal Management, 80: 133-148.

http://dx.doi.org/10.1016/j.ocecoaman.2013.02.013.
Ghosh C.C., 1912. The big brown cricket. Memories of the Department of Agriculture in India, 4: 161-182.

Grandi G., 1951. Introduzione allo studio della entomologia. Vol. I. Edizioni Agricole, Bologna, 614 pp.

Ientile R. \& Andreotti A., 2003. Primi casi di riproduzione del Pollo sultano Porphyrio porphyrio in Sicilia a seguito del Progetto di reintroduzione in corso. Rivista Italiana di Ornitologia, 73: 83-86.

ISPRA-Ministero dell'Ambiente, 2016a. Manuali per il monitoraggio di specie e habitat di interesse comunitario (Direttiva 92/43/CEE) in Italia: Specie animali, 141/2016.

ISPRA-Ministero dell'Ambiente, 2016b. Manuali per il monitoraggio di specie e habitat di interesse comunitario (Direttiva 92/43/CEE) in Italia: Habitat, 142/2016.

La Greca M., 1977. Parco del Simeto: progetto nuovo per Catania. Problemi (Periodico della CGIL): n. 4, Catania.

Lakhdari W., 2015. Bioécologie de Brachytrupes megacephalus Lefèbvre, 1827 (Orthoptera, Gryllidae) et lutte biologique par l'utilization de chempignons entomopathogènes. Thèse de doctorat en sciences agronomiques. Université Kasdi Merbah. Ouargla, Algerie.

Lakhdari W., Doumandji-Mitiche B., Dahliz A., Doumandji S., Bendifellah L., Bouchikh Y., Hammi H., Soud A., M'lik R., 2015a. Host Plant Determination of Brachytrupes megacephalus Lefebvre, 1827 (Orthoptera, Grillinae) Using Faeces Analysis in the Region of Oued Righ (Algerian Sahara). American-Eurasian Journal of Agricultural \& Environmental Sciences, 15: 271-277.

Lakhdari W., Doumandji-Mitiche B., Dahliz A., Acheuk F., Hammi H., M'lik R. \& Soud A., 2015b. Some Elements of the Bio-ecology of Brachytrupes megacephalus Lefebvre, 1827 (Orthoptera, Gryllidae) in the Region of Oued Righ (Algerian Sahara). American-Eurasian Journal of Agricultural \& Environmental Sciences, 15: 1082-1089.

Lakhdari W., Doumandji-Mitiche B., Acheuk F., Dehliz A., Hammi H., M'lik R., Soud A., Doumandji S., 2015c. Morphology and structure of adult male genitalia of Brachytrupes megacephalus Lefebvre, 1827 (Orthoptera, Gryllidae) in the southeast of Algeria. Journal of Entomology and Zoology Studies 3: 355-359.

Lakhdari W., Doumandji Mitich B., Dahliz A., Doumandji S., Bouchikh Y., M'lik R., Soud A., Hammi H., 2015d. Essai de lutte biologique contre Brachytrupes megacephalus Lefebvre, 1827 (Orthoptera, Gryllinae) par l'utilisation des champignons entomopathogenes. Revue des BioRessources, 15: 37-49.

Lefebvre A., 1827. Annales de la Sociéte Linnéenne de Paris. VI Volume des Mémoires. Imprimerie de E. Pochard, Paris, pp. 99-102. 
Leonardi G., 1901. Gli insetti nocivi. Ed. Eugenio Marghieri, Napoli, pp. 752-754.

Longhitano S. \& Colella A., 2007. Geomorphology, sedimentology and recent evolution of the anthropogenically modified Simeto River delta system (eastern Sicily, Italy). Sedimentary Geology, 194: 195-221.

Maltese G., 2002. Osservazioni sulla eco-etologia di Brachytrupes megacephalus Lefebvre, 1827 (Orthoptera, Gryllidae). Tesi di Laurea. Relatore: prof. Alfredo Petralia. Università degli Studi di Catania. Anno accademico 2002-2003.

Okeke T.E., Ewuim S.C., Akunne C.E. \& Ononye B.U., 2019. Survey of edible insects in relation to their habitat and abundance in Awka and environ. International Journal of Entomology Research, 4: 17-21.

Petralia A., Russo C. \& Cartarrasa S., 2003. Topology of Brachytrupes megacephalus (Lefebvre, 1827) (Orthoptera, Gryllidae) in some Sicilian Natural reserves. Atti "Fifth International Symposium on GIS and Computer Cartography for Coastal Zone Management", Genova 2003.

Petralia A., Petralia E., Sabella G., Brogna F. \& Bianca C., 2015. Presence's mapping of Brachytrupes megacephalus (Lefebrve, 1827) (Orthoptera, Gryllidae) within the Natural Reserve of Vendicari (Noto, Siracusa, Italy). Biodiversity Journal, 6: 323-326.

Provincia di Catania, 2010. Piano di Gestione del sito "Fiume Simeto". A cura di NIER Ingegneria Spa, Bologna.

Ronsisvalle G., 1978. Vegetazione alofila e psammofila presso la foce del Simeto (Catania). Bollettino delle sedute della Accademia Gioenia di Scienza Naturali in Catania, 13: 9-25.

Salviamo il Paesaggio, 2012. http://www.salviamoilpaesaggio.it/blog/2012/06/ca tania-nuove-case-abusivenelloasi-del-simeto-le-as sociazioni-in-rivolta/

Scortecci G., 1960. Animali. Insetti I. Edizioni Bolis, Bergamo.

Sivestri F., 1939. Compendio di entomologia applicata. Parte speciale, Vol. I. Tipografia Bellavista, Napoli, pp. 85-86.

Torrisi G., 2019. Relazione Programmatica 2019 relativa alla gestione della R.N.O. "Oasi del Simeto". Città Metropolitana di Catania: Ufficio Gestione Riserve.

Van der Sluis T. \& Pedroli B., 2003. Analisi spaziale sull' Oasi del Simeto. Alterra, Green World Research, Wageningen, Alterra-rapport, 644 pp.

Van Huis A., 2003. Insect as Food in Sub-Saharian Africa. Insect Science and its Application, 23: 163-185.

Van Itterbeeck J., Irina N. Rakotomalala Andrianavalona I.N., Rajemison F.I., Johanna F. Rakotondrasoa J.F., Ralantoarinaivo V.R., Hugel S. \& Fisher B.L., 2019. Diversity and Use of Edible Grasshoppers, Locusts, Crickets, and Katydids (Orthoptera) in Madagascar. Foods, 8, 666: 2-19. (www.mdpi.com/ journal/foods).

Vagliasindi G., 1933. La bonifica integrale in Sicilia e nella Piana di Catania. Bonifica e colonizzazione, n. 4, aprile 1933.

Zanardi D., 1964. Un singolare insetto dannoso a vigneti e orti in Sardegna. Il Brachytrypes megacephalus Lefeb. Il coltivatore e Giornale vinicolo italiano, 110: 370-375. 